\title{
Performance of warm-season turfgrasses under different water regimes in the Mediterranean climate conditions of Southern Italy
}

\author{
Vito Marchione, Mariano Fracchiolla \\ Department of Agricultural and Environmental Science, University of Bari, Italy
}

\begin{abstract}
In Mediterranean areas, very scarce rainfalls during the summer season are a limiting factor to the sowing and managing of turfgrasses. This work evaluates the response to different irrigation regimes (50 or 75\% of reference evapotranspiration) of Cynodon dactylon (L.) Pers. cv Transcontinental, Paspalum vaginatum Swartz cv Salam, Pennisetum clandestinum (Chiov.) Hochst. cv AZ1, Stenotaphrum secundatum (Walt.) Kuntze cv Palmetto and Zoysia japonica Steud. cv El Toro. Performance of turfgrasses was evaluated in term of turf quality, colour index and ground cover.

Only when rainfalls were scarce, water regime restoring the $75 \%$ of the evapotranspiration $\left(\mathrm{ET}_{0}\right)$ showed significant effects. Under rainy conditions, the restoration of only the $50 \%$ of $\mathrm{ET}_{0}$ was able to give highly acceptable values. The best performance was observed for $Z$. japonica, $C$. dactylon and $P$. vaginatum, whereas $P$. clandestinum and $S$. secundatum showed lower adaptability to water stress.
\end{abstract}

\section{Introduction}

Both in public or private urban areas, turf assumes considerable importance to complete the function of shrubs and trees and to allow safe recreational activities and sports. Nevertheless, in Mediterranean areas, very scarce rainfalls during the summer season are a limiting factor to the sowing and managing of turfgrasses.

Correspondence: Mariano Fracchiolla, Department of Agricultural and Environmental Science, University of Bari, via Amendola 165/A, 70126 Bari, Italy.

E-mail: mariano.fracchiolla@uniba.it

Key words: Turf quality; drought stress; environmental adaptability; climatic variability.

Conflict of interest: the authors declare no potential conflict of interest.

Received for publication: 5 February 2016.

Revision received: 27 April 2016.

Accepted for publication: 30 April 2016.

(C) Copyright V. Marchione and M. Fracchiolla, 2016

Licensee PAGEPress, Italy

Italian Journal of Agronomy 2016; 11:766

doi:10.4081/ija.2016.766

This article is distributed under the terms of the Creative Commons Attribution Noncommercial License (by-nc 4.0) which permits any noncommercial use, distribution, and reproduction in any medium, provided the original author(s) and source are credited.
Water requirement of turfgrass is used to maintain both functional and visual quality, depending on the specific purpose (decorative, sports, technical) for which it was established (Kneebone et al., 1992).

Many warm-season C4 plants belonging to the Poaceae family and originating from Tropical and Sub-Tropical regions are tolerant to drought and high temperatures (Sifer and Beard, 1999; Oula, 2009).

Over the past thirty years, several studies have addressed the evaluation of water requirements. Researches stressed the effects on the evapotranspiration rates of environmental factors (climate, moisture, soil), or managing techniques (William, 1982; Feldake, 1984) and the differences between cool-season and warm-season grasses (Beard, 1985; Bowman and Macaulay, 1991; Carrow, 1996).

Shearman (1986) showed high correlation between turfgrass quality and evapotranspiration; Aronson et al. (1987) studied the effects of drought stress on quality, growing and evapotranspiration; Kneebone et al. (1992) evaluated water requirements of Cynodon dactylon (L.) Pers. reporting values ranging from 2.5 and $7.5 \mathrm{~mm} \mathrm{~d}^{-1}$.

Many researches have addressed the differences of evapotranspiration between cool-season and warm-season grasses under different climate conditions (Kim and Beard, 1988; Kopec et al., 1988; Zhang et al., 2007). For several warm-season species, Carrow (1996) and Huang et al. $(1997 \mathrm{a}, 1997 \mathrm{~b})$ studied the relation between drought tolerance and the depth of their root systems.

Meyer and Gibault (1986) highlighted that warm-season species have water requirement lower than cool-season species with a crop coefficient (Kc) respectively ranging from 0.6-0.7 and 0.8-1.

Other researches evaluated the physiological adaptation or the functional and qualitative response of different cool and warm season grasses to increasing water deficits (Miele et al., 1995; Qian and Engelke, 1999; Bastug and Buyuktas, 2003; Marchione, 2003; Cereti et al., 2004; Fu and Huang, 2004). All these studies report that, during the summer period, warm-season grasses are more tolerant to drought stress than cool-season grasses.

Many other works evaluated the tolerance to long water stresses of warm-season grasses (Qian and Fry, 1997; Severmutulu et al., 2011; Cathey and Kruse, 2011) and the response to different irrigation regimes (Biran et al., 1981; Qian and Engelke, 1999; Fu and Huang, 2004; Banuelos et al., 2011; Marchione, 2012).

This work evaluates the response, in terms of visual quality, of five warm-season turfgrasses irrigated with different water volumes. The trial was conducted in Southern Italy under Mediterranean climate conditions and results could be useful to suggest best practices to save water resources for the managing of turfgrasses in this area.

\section{Materials and methods}

The research was performed from June to September both in 2008 and 2009 in a Farm at Polignano a Mare (Apulia - Southern Italy $40^{\circ} 58^{\prime} 35.05^{\prime \prime} \mathrm{N}, 17^{\circ} 12^{\prime} 46.32^{\prime \prime} \mathrm{E}$ ) and evaluated the response of five warm season grasses to two different irrigation volumes.

The following species, established during the spring of 2006, were 
compared: Cynodon dactylon (L.) Pers. cv Transcontinental, Paspalum vaginatum Swartz cv Salam, Pennisetum clandestinum (Chiov.) Hochst. cv AZ1, Stenotaphrum secundatum (Walt.) Kuntze cv Palmetto and Zoysia japonica Steud. cv El Toro. Irrigation volumes were calculated as restoration of 50 or $75 \%$ of weekly reference evapotranspiration $\left(\mathrm{ET}_{0}\right)$ subtracting the total rainfall of the same period (Table 1) according to the methodology used by other similar researches (Meyer and Gibeault, 1986; Zhang et al., 2007).

Main physical and chemical properties of the soil of the experimental site are shown in Table 2.

The experiment was established as a split-plot design with three replicates; water volumes (50 and $75 \% \mathrm{ET}_{0}$ ) were arranged in the main plots whereas the species were sown in the sub-plots $\left(8.0 \mathrm{~m}^{2}\right)$.

In each year, turfgrass was weekly irrigated between June and September; at the beginning of the irrigation season soil was brought to the field capacity.

A scale ranging from 1 to 9 was used to evaluate turf quality (from worst to best) and colour index (from completely brown to bright green). Ground cover was expressed as percentage of the plot covered by the green turf. Indexes were visually estimated every 15 days.

Turfgrass was managed with the standard practices of the area, including two fertilisations (in June and July) with slow release fertiliser (15-9-15\% of nitrogen, phosphorus and potassium) at a dose of $40 \mathrm{~g} \mathrm{~m}^{-2}$, chemical weeding against broadleaf weeds (MCPA+Dicamba) and weekly mowing to a height of $4 \mathrm{~cm}$.

The irrigation system consisted of polyethylene pipes PN4 ø 32; the sprinklers had an opening angle of $90^{\circ}$ and $180^{\circ}$ and were arranged on the outer side of plots.

Data were subjected to analysis of variance according to the splitsplit-plot experimental design. Irrigation rate was put in the main plots (main effect) species were put in the sub-plots whereas months were considered as sub-sub-plot (Gomez and Gomez, 1984). Means were compared with Student-Newman-Keuls's or Fisher's least significant difference test. The paper reports the monthly mean data.

\section{Climate data}

The climate data (Table 1) were detected with an automatic weather station (Davis-Weather Pro) adjacent the experimental field and they were used to determinate the reference $\mathrm{ET}_{0}$ according to PenmanMonteith method.

Both in 2008 and in 2009, the highest average temperatures were in July and August with values ranging around $30^{\circ} \mathrm{C}$; in the same months, several times, the highest temperatures reached $40^{\circ} \mathrm{C}$ (data not shown) and rainfalls were negligible or absent.

Total rainfalls between June and September of the second year of the trial were $156 \mathrm{~mm}$, while in the first year this value was significantly lower and equal to $38 \mathrm{~mm}$.

Cumulative $\mathrm{ET}_{0}$ from June to September was equal to $613 \mathrm{~mm}$ in the 2008 and $563 \mathrm{~mm}$ in 2009 ; the highest monthly values were observed in July of both years.

Table 1. Monthly climatic data (average of daily recorded values) and cumulative irrigation volumes applied.

\begin{tabular}{|c|c|c|c|c|c|c|c|c|c|c|}
\hline Years & Months & $\begin{array}{l}\text { T. } \max \\
\left({ }^{\circ} \mathrm{C}\right)\end{array}$ & $\begin{array}{l}\text { T. min } \\
\left({ }^{\circ} \mathrm{C}\right)\end{array}$ & $\begin{array}{l}\text { RH } \\
(\%)\end{array}$ & $\begin{array}{l}\text { Wind speed } \\
\qquad(\mathrm{m} / \mathrm{s})\end{array}$ & $\begin{array}{l}\text { Monthly } \\
\text { rainfall }\end{array}$ & $\begin{array}{c}\mathrm{ET}_{0} \\
(\mathrm{~mm})\end{array}$ & $\begin{array}{c}\mathrm{ET}_{0} \text {-rainfall } \\
(\mathrm{mm})\end{array}$ & & \\
\hline & & & & & & (mm) & & & $V_{1}$ & $\mathrm{~V}_{2}$ \\
\hline 2008 & June & 28.2 & 19.1 & 60.1 & 1.4 & 10 & 155 & 145 & 73 & 109 \\
\hline & July & 30.3 & 21.7 & 51.6 & 1.7 & 5 & 188 & 183 & 91 & 137 \\
\hline & August & 30.7 & 21.6 & 51.5 & 1.4 & 0 & 169 & 169 & 84 & 127 \\
\hline & September & 24.8 & 17.2 & 61.2 & 1.5 & 23 & 101 & 78 & 39 & 59 \\
\hline June-Se & nber & 28.5 & 19.9 & 56.1 & 1.5 & 38 & 613 & 575 & 288 & 432 \\
\hline 2009 & June & 26.9 & 17.7 & 61.2 & 1.1 & 57 & 138 & 81 & 40 & 61 \\
\hline & July & 30.2 & 21.4 & 52.1 & 1.3 & 15 & 176 & 161 & 80 & 121 \\
\hline & August & 30.0 & 21.9 & 60.8 & 1.3 & 4 & 152 & 148 & 74 & 111 \\
\hline & September & 25.9 & 18.7 & 70.7 & 1.1 & 80 & 97 & 17 & 9 & 13 \\
\hline June-Se & nber & 28.2 & 19.9 & 61.2 & 1.2 & 156 & 563 & 407 & 203 & 306 \\
\hline
\end{tabular}

T., temperature; $\mathrm{RH}$, relative humidity; $\mathrm{ET}_{0}$, evapotranspiration. ${ }^{*} \mathrm{~V}_{1}=50 \% \mathrm{ET}_{0} ; \mathrm{V}_{2}=75 \% \mathrm{ET}_{0}$.

Table 2. Main physical and chemical properties of the soil of the experimental site.

\begin{tabular}{|c|c|}
\hline Texture & Clay $(\%)=30.6 ;$ Loam $(\%)=48.0 ;$ Sand $(\%)=21.4$ USDA Classification: Sandy Clay Loam \\
\hline Field capacity & $23.4 \%$ \\
\hline Wilting point & $13.6 \%$ \\
\hline $\mathrm{pH}$ & 7.6 \\
\hline Electrical conductivity & $0.8 \mathrm{ds} \mathrm{m}^{-1}$ \\
\hline Total limestone (calcimetric method) & $1.7 \%$ \\
\hline Organic matter (Walkley-Black method) & $2.65 \%$ \\
\hline Available phosphorus (Olsen method) & $30 \mathrm{mg} \mathrm{kg}^{-1}$ of $\mathrm{P}_{2} \mathrm{O}_{5}$ \\
\hline Available potassium ( $\mathrm{BaCl}_{2}$ method) & $187.0 \mathrm{mg} \mathrm{kg}^{-1}$ of $\mathrm{K}_{2} \mathrm{O}$ \\
\hline
\end{tabular}

USDA, United States Department of Agriculture. 


\section{Results and discussion}

With exception for the interaction between species and water regimes, analysis of variance showed significant differences both among the main effects and among interactions (Table 3).

In both years, restoration of $75 \%$ of weekly reference $\mathrm{ET}_{0}$ gave the highest values of turf quality, colour index and ground cover percentage (Table 4). This effect was particularly clear in 2008 when the highest water regime gave values respectively equal to $6.8-6.8-82.0 \%$, higher than the values estimated for $\mathrm{ET}_{0} 50 \%$ (5.8-5.5-62\%). In the second year, the increased rainfall determined less marked differences between water regimes and, even with the reduced irrigation volume $\left(50 \% \mathrm{ET}_{0}\right)$, all the values estimated were quite acceptable (6.6-6.5-73\%).

The highest indexes were evaluated in June and September of both years (Table 5). Turf quality indexes were respectively estimated equal to 6.7-6.8 in 2008 and 7.2-7.3 in 2009. Colour index gave values respectively of 6.7-6.6 in 2008 and 7.1-7.3 in 2009. Ground cover percentage was estimated equal to $76-75 \%$ in 2008 and $86-88 \%$ in 2009 . It is likely to suppose that all values are higher in 2009 than in 2008 due to the more abundant rainfalls.
Regarding the effect of species (Table 6), in 2008 colour, quality and ground cover indexes of $Z$. japonica were respectively estimated equal to $6.5-6.4$ and $75 \%$ and statistically higher than in the other species compared. Also in 2009 this species showed the highest indexes; nevertheless, values of quality (7.0) and ground cover (81.0\%) were statistically different only from those estimated for P. clandestinum (6.6 and $74 \%)$ and colour index was significantly different only from those estimated for $S$. secundatum (6.7), $C$. dactylon (6.8) and $P$. clandestinum (6.5). Also for the differences among species, the less marked effects recorded in 2009 could be explained with the more abundant rainfalls recorded in this year.

These results are consistent with the research conducted both under water stress and under optimum water supply conditions by Zhang et al. (2007). Results report that $Z$. japonica has lower values of Kc than other warm-season species (including $C$. dactylon) and thus requires lower irrigation volumes. Moreover, Carmo-Silva et al. (2009) studied some physiological and morphological mechanism of adaptation to aridity of Paspalum dilatatum Poir., C. dactylon and Z. japonica. Authors suggest that the drought tolerance can be promoted also by the massive presence of cells with rigid cell walls and by the osmotic

Table 3. Analysis of variance of the effects and interactions of water regimes, species and months on turf quality, ground cover and colour index in 2008 and 2009.

\begin{tabular}{|c|c|c|c|c|c|c|}
\hline \multirow[t]{3}{*}{ Effects } & \multicolumn{6}{|c|}{ Quality indexes* } \\
\hline & \multicolumn{2}{|c|}{ Turf quality ${ }^{\circ}$} & \multicolumn{2}{|c|}{ Colour\# } & \multicolumn{2}{|c|}{ Ground cover ${ }^{\S}$} \\
\hline & 2008 & 2009 & 2008 & 2009 & 2008 & 2009 \\
\hline \multicolumn{7}{|l|}{ Main } \\
\hline Water regimes & * & $*$ & * & $*$ & $*$ & $*$ \\
\hline Species & * & $*$ & $*$ & * & $*$ & * \\
\hline Months & * & $*$ & $*$ & $*$ & $*$ & * \\
\hline \multicolumn{7}{|l|}{ Interactions } \\
\hline Species $\times$ water regimes & ns & ns & ns & ns & ns & ns \\
\hline Months $\times$ water regimes & $*$ & $*$ & $*$ & ns & $*$ & $*$ \\
\hline Months $\times$ species & $*$ & * & $*$ & $*$ & $*$ & * \\
\hline Months $\times$ species $\times$ water regimes & $*$ & $*$ & $*$ & $*$ & $*$ & * \\
\hline
\end{tabular}

*Significant at P<0.05; ㄱom 1 (worst) to 9 (best); "from 1 (completely brown) to 9 (bright green); $\$ \%$ of the plot covered by the green turf. ns, not significant.

Table 4. Effect of water regimes on turf quality, ground cover and colour index in 2008 and 2009.

\begin{tabular}{|c|c|c|c|c|c|c|}
\hline \multirow[t]{3}{*}{ Water regimes* } & \multicolumn{6}{|c|}{ Quality indexes } \\
\hline & \multicolumn{2}{|c|}{ Turf quality ${ }^{\circ}$} & \multicolumn{2}{|c|}{ Colour ${ }^{\#}$} & \multicolumn{2}{|c|}{ Ground cover } \\
\hline & 2008 & 2009 & 2008 & 2009 & 2008 & 2009 \\
\hline 75 & 6.8 & 7.2 & 6.8 & 7.1 & 82 & 86 \\
\hline 50 & 5.8 & 6.6 & 5.5 & 6.5 & 62 & 73 \\
\hline $\operatorname{LSD}(\mathrm{P}<0.05)$ & 0.2 & 0.1 & 0.3 & 0.2 & 1.5 & 2.7 \\
\hline
\end{tabular}

*Expressed as restoration of weekly evapotranspiration (\%); ${ }^{\circ}$ from 1 (worst) to 9 (best); "from 1 (completely brown) to 9 (bright green); ${ }^{8} \%$ of the plot covered by the green turf. LSD, least significant difference.

Table 5. Effect of months on turf quality, ground cover and colour index in 2008 and 2009.

\begin{tabular}{|c|c|c|c|c|c|c|}
\hline \multirow[t]{3}{*}{ Months } & \multicolumn{6}{|c|}{ Quality indexes* } \\
\hline & \multicolumn{2}{|c|}{ Turf quality ${ }^{\circ}$} & \multicolumn{2}{|c|}{ Colour\# } & \multicolumn{2}{|c|}{ Ground cover ${ }^{\S}$} \\
\hline & 2008 & 2009 & 2008 & 2009 & 2008 & 2009 \\
\hline June & $6.7^{\mathrm{a}}$ & $7.2^{\mathrm{a}}$ & $6.7^{\mathrm{a}}$ & $7.1^{\mathrm{a}}$ & $76^{\mathrm{a}}$ & $86^{\mathrm{a}}$ \\
\hline July & $5.8^{c}$ & $6.6^{\mathrm{b}}$ & $5.4^{\mathrm{c}}$ & $6.5^{\mathrm{b}}$ & $64^{c}$ & $74^{\mathrm{b}}$ \\
\hline August & $5.9^{\mathrm{b}}$ & $6.4^{\mathrm{c}}$ & $5.9^{\mathrm{b}}$ & $6.3^{c}$ & $71^{b}$ & $71^{c}$ \\
\hline September & $6.8^{\mathrm{a}}$ & $7.3^{\mathrm{a}}$ & $6.6^{\mathrm{a}}$ & $7.3^{\mathrm{a}}$ & $75^{\mathrm{a}}$ & $88^{a}$ \\
\hline
\end{tabular}

*In each column, means followed by different letters are significantly different ( $\mathrm{P}<0.05$; Student-Newman-Keuls's test); ${ }^{\circ}$ from 1 (worst) to 9 (best); ${ }^{\sharp}$ from 1 (completely brown) to 9 (bright green); ${ }^{\S} \%$ of the plot covered by the green turf. 
adjustment by foliar accumulation of amino acids, in particular proline. Both of these mechanisms appear to be more efficient in $Z$. japonica than in $C$. dactylon.

Regarding the combined effects of months either with water regimes or with species, with exception for colour index in 2009, significant interactions where found for all the properties evaluated in both years (Table 3).

Particularly for the interaction between months and water regimes (Table 7), the largest differences of quality and colour index in response to the irrigation regimes were observed in July and August of the first year (2008). The severe drought and higher cumulative values of $\mathrm{ET}_{0}$ in these months most influenced turf quality. As a matter of fact, for the irrigation regime of $75 \% \mathrm{ET}_{0}$ turf quality index was estimated equal to 6.5 , statistically higher than those estimated for $50 \% \mathrm{ET}_{0}(5.2$ in July and 5.3 in August).

Months that were more rainy and characterised by lower $\mathrm{ET}_{0}$ gave less marked differences among all parameters estimated. Particularly, in September of 2009 (Table 7) turf quality and colour index were estimated equal to 7.5 and 7.1 respectively for 75 and $50 \%$ of $\mathrm{ET}_{0}$, while ground cover was 93 and $83 \%$. Although these data, with exception for colour index, are statistically different from each other, differences are scarce and values can be considered overall acceptable.

Moreover, for turf quality and ground cover, all the values estimated with the lower irrigation level in September $\left(50 \% \mathrm{ET}_{0}\right)$ are statistically higher than those estimated, even for the $\mathrm{ET}_{0} 75 \%$, in July and August. This result is a further confirmation of the deep effect of rainfalls on the parameters estimated.

Table 8 reports the effects of months on performances of the species evaluated. These data have been influenced mainly by climatic conditions occurred during the two years of trial. In the first year, characterised by hot temperatures, negligible rainfalls and higher evapotranspiration rate particularly during July, turf quality was estimated lower than 6 for all species tested except for $Z$. japonica. Good values were observed in June and overall in September, with mild temperatures and the occurrence of rainfall. $Z$. japonica gave the best results, while $P$. clandestinum the worst. For the others two parameters (colour index and ground cover percentage), similar results were detected. A different behaviour was observed in the second year; thanks to adequate rainfall and lower evapotranspiration rate, turf quality values for all species were $>6$, ranging from 6.1 for $P$. clandestinum in August and 7.7 for Z. japonica in September. Similar results for colour index and ground cover percentage were found. The highest values were estimated for Z. japonica while the worst were observed for P. clandestinum.

The $3^{\text {rd }}$ order interactions (water regimes $\times$ species $\times$ months) showed significantly differences for all characters estimated in both years. For reasons of brevity, in the paper only the results of analysis of variance are shown (Table 3 ) whereas the data are commented below.

In the first year (2008), characterised by lower rainfall and higher evapotranspiration demand, the effect of irrigation regimes was more evident. In fact all species compared showed good values $(\geq 6.5)$ for turf quality only when irrigated, during June-August, with higher irrigation regimes $\left(\mathrm{ET}_{0}=75 \%\right)$. The effect of rainfall and lower cumulative evapotranspiration during September also increased values for all species; among these, better results were shown by $Z$. japonica (7.6) and $P$. vaginatum (7.2). The worst values ( $\leq 5.0)$ were recorded in July for all species when irrigated with the lower irrigation regimes $\left(\mathrm{ET}_{0}=50 \%\right)$; in

Table 6. Effect of species on turf quality, ground cover and colour index in 2008 and 2009.

\begin{tabular}{|c|c|c|c|c|c|c|}
\hline \multirow[t]{3}{*}{ Species } & \multirow{2}{*}{\multicolumn{4}{|c|}{$\begin{array}{l}\text { Quality indexes* } \\
\text { Colour\# }\end{array}$}} & \multirow{2}{*}{\multicolumn{2}{|c|}{ Ground cover ${ }^{\S}$}} \\
\hline & & & & & & \\
\hline & 2008 & 2009 & 2008 & 2009 & 2008 & 2009 \\
\hline Zoysia japonica & $6.5^{\mathrm{a}}$ & $7.0^{\mathrm{a}}$ & $6.4^{\mathrm{a}}$ & $6.9^{\mathrm{a}}$ & $75^{\mathrm{a}}$ & $81^{\mathrm{a}}$ \\
\hline Stenotaphrum secundatum & $6.3^{\mathrm{b}}$ & $6.9^{\mathrm{a}}$ & $6.0^{\mathrm{b}}$ & $6.7^{\mathrm{b}}$ & 72 & $79^{\mathrm{a}}$ \\
\hline Paspalum vaginatum & $6.3^{\mathrm{b}}$ & $7.0^{\mathrm{a}}$ & $6.1^{\mathrm{b}}$ & $7.0^{\mathrm{a}}$ & $73^{b}$ & $81^{\mathrm{a}}$ \\
\hline Cynodon dactylon & $6.3^{b}$ & $7.0^{\mathrm{a}}$ & $6.1^{\mathrm{b}}$ & $6.8^{\mathrm{b}}$ & $69^{c}$ & $81^{\mathrm{a}}$ \\
\hline Pennisetum clandestinum & $6.2^{\mathrm{b}}$ & $6.6^{\mathrm{b}}$ & $6.1^{\mathrm{b}}$ & $6.5^{c}$ & $70^{c}$ & $74^{b}$ \\
\hline
\end{tabular}

${ }^{*}$ In each column, means followed by different letters are significantly different $\left(\mathrm{P}<0.05\right.$; Student-Newman-Keuls’s test); ${ }^{\circ}$ from 1 (worst) to 9 (best); ${ }^{\sharp}$ from 1 (completely brown) to 9 (bright green); ${ }^{\S} \%$ of the plot covered by the green turf.

Table 7. Combined effects of months and water regimes on turf quality, ground cover and colour index in 2008 and 2009.

\begin{tabular}{|c|c|c|c|c|c|c|c|}
\hline \multirow[t]{3}{*}{ Months } & \multirow[t]{3}{*}{ Water regimes $^{\circ}$} & \multicolumn{4}{|c|}{ Quality indexes* } & \multirow{2}{*}{\multicolumn{2}{|c|}{ Ground cover ${ }^{\wedge}$}} \\
\hline & & \multicolumn{2}{|c|}{ Turf quality\# } & \multicolumn{2}{|c|}{ Colour ${ }^{\S}$} & & \\
\hline & & 2008 & 2009 & 2008 & 2009 & 2008 & 2009 \\
\hline \multirow[t]{2}{*}{ June } & 75 & $7.0^{\mathrm{a}}$ & $7.4^{\mathrm{a}}$ & $7.0^{\mathrm{a}}$ & 7.4 & $87^{\mathrm{a}}$ & $93^{\mathrm{a}}$ \\
\hline & 50 & $6.4^{\mathrm{c}}$ & $6.9^{c}$ & $6.3^{\mathrm{b}}$ & 6.9 & $73^{b}$ & $79 c$ \\
\hline \multirow[t]{2}{*}{ July } & 75 & $6.5^{c}$ & $6.9^{c}$ & $6.1^{\mathrm{b}}$ & 6.8 & $64^{c}$ & $79 c$ \\
\hline & 50 & $5.2^{\mathrm{d}}$ & $6.3^{\mathrm{d}}$ & $4.7^{c}$ & 6.2 & $57^{\mathrm{d}}$ & $68^{d}$ \\
\hline \multirow[t]{2}{*}{ August } & 75 & $6.5^{c}$ & $6.8^{c}$ & $6.2^{\mathrm{b}}$ & 6.6 & $67^{c}$ & $78^{c}$ \\
\hline & 50 & $5.3^{\mathrm{d}}$ & $6.1^{\mathrm{d}}$ & $4.9^{c}$ & 6.0 & $59^{\mathrm{d}}$ & $63^{\mathrm{e}}$ \\
\hline \multirow[t]{2}{*}{ September } & 75 & $7.1^{\mathrm{a}}$ & $7.5^{\mathrm{a}}$ & $7.0^{\mathrm{a}}$ & 7.5 & $90^{\mathrm{a}}$ & $93^{\mathrm{a}}$ \\
\hline & 50 & $6.7^{\mathrm{b}}$ & $7.1^{\mathrm{b}}$ & $6.2^{\mathrm{b}}$ & 7.1 & $75^{b}$ & $83^{b}$ \\
\hline
\end{tabular}

*In each column, means followed by different letters are significantly different $\left(\mathrm{P}<0.05 ;\right.$ Student-Newman-Keuls's test); ${ }^{\circ}$ expressed as restoration of weekly evapotranspiration (\%); ${ }^{\sharp}$ from 1 (worst) to 9 (best); ${ }^{\S}$ from 1 (completely brown) to 9 (bright green); $\wedge \%$ of the plot covered by the green turf. 
Table 8. Combined effects of months and species on turf quality, colour index and ground cover in 2008 and 2009.

\begin{tabular}{|c|c|c|c|c|c|c|c|}
\hline \multirow[t]{2}{*}{ Months } & \multirow[t]{2}{*}{ Species } & \multicolumn{2}{|c|}{ Turf quality* } & \multicolumn{2}{|c|}{ Colour index ${ }^{\circ}$} & \multicolumn{2}{|c|}{ Ground cover $(\%)^{\#}$} \\
\hline & & 2008 & 2009 & 2008 & 2009 & 2008 & 2009 \\
\hline \multirow[t]{5}{*}{ June } & Z. japonica & $6.4^{\mathrm{d}}$ & $6.9^{c}$ & $6.3^{c}$ & $7.0^{c}$ & $71^{\mathrm{d}}$ & $82^{\mathrm{e}}$ \\
\hline & S. secundatum & $7.0^{\mathrm{b}}$ & $7.3^{b}$ & $7.0^{\mathrm{a}}$ & $7.3^{\mathrm{b}}$ & $80^{\mathrm{b}}$ & $87^{c}$ \\
\hline & P. vaginatum & $6.7^{\mathrm{c}}$ & $7.3^{b}$ & $6.5^{\mathrm{b}}$ & $7.3^{b}$ & $77^{\mathrm{c}}$ & $88^{c}$ \\
\hline & C. dactylon & $6.7^{c}$ & $7.4^{\mathrm{b}}$ & $6.6^{\mathrm{b}}$ & $7.3^{b}$ & $76^{\mathrm{c}}$ & $90^{\mathrm{b}}$ \\
\hline & P. clandestinum & $6.7^{\mathrm{c}}$ & $6.9^{c}$ & $6.9^{\mathrm{a}}$ & $7.0^{c}$ & $77^{\mathrm{c}}$ & $80^{\mathrm{f}}$ \\
\hline \multirow[t]{5}{*}{ July } & Z. japonica & $6.4^{\mathrm{d}}$ & $6.7^{\mathrm{d}}$ & $6.3^{\mathrm{c}}$ & $6.7^{\mathrm{d}}$ & $72^{\mathrm{d}}$ & $75^{\mathrm{h}}$ \\
\hline & S. secundatum & $5.6^{\mathrm{f}}$ & $6.6^{\mathrm{d}}$ & $4.7^{\mathrm{g}}$ & $6.2^{f}$ & $62^{\mathrm{f}}$ & $75^{\mathrm{h}}$ \\
\hline & P. vaginatum & $5.6^{\mathrm{f}}$ & $6.5^{\mathrm{e}}$ & $5.3^{\mathrm{f}}$ & $6.4^{\mathrm{e}}$ & $62^{\mathrm{f}}$ & $71^{\mathrm{i}}$ \\
\hline & C. dactylon & $5.8^{\mathrm{e}}$ & $6.9^{c}$ & $5.6^{\mathrm{e}}$ & $6.8^{\mathrm{d}}$ & $62^{f}$ & $78^{g}$ \\
\hline & P. clandestinum & $5.6^{\mathrm{f}}$ & $6.4^{\mathrm{e}}$ & $5.2^{f}$ & $6.2^{f}$ & $61^{\mathrm{f}}$ & $68 \mathrm{j}$ \\
\hline \multirow[t]{5}{*}{ August } & Z. japonica & $6.0^{\mathrm{e}}$ & $6.5^{\mathrm{e}}$ & $6.0^{\mathrm{d}}$ & $6.3^{\mathrm{e}}$ & $72^{\mathrm{d}}$ & $71^{\mathrm{i}}$ \\
\hline & S. secundatum & $6.0^{\mathrm{e}}$ & $6.3^{\mathrm{f}}$ & $5.8^{\mathrm{e}}$ & $6.2^{\mathrm{f}}$ & $70^{\mathrm{d}}$ & $70^{\mathrm{i}}$ \\
\hline & P. vaginatum & $6.0^{\mathrm{e}}$ & $6.7^{\mathrm{d}}$ & $6.0^{\mathrm{d}}$ & $6.7^{\mathrm{d}}$ & $77^{\mathrm{c}}$ & $78^{g}$ \\
\hline & C. dactylon & $6.0^{\mathrm{e}}$ & $6.4^{\mathrm{e}}$ & $6.1^{\mathrm{d}}$ & $6.2^{\mathrm{f}}$ & $66^{\mathrm{e}}$ & $68 \mathrm{j}$ \\
\hline & P. clandestinum & $5.8^{\mathrm{e}}$ & $6.1^{\mathrm{g}}$ & $5.8^{\mathrm{e}}$ & $5.9^{g}$ & $72^{\mathrm{d}}$ & $65^{1}$ \\
\hline \multirow[t]{5}{*}{ September } & Z. japonica & $7.3^{\mathrm{a}}$ & $7.7^{\mathrm{a}}$ & $7.1^{\mathrm{a}}$ & $7.7^{\mathrm{a}}$ & $84^{\mathrm{a}}$ & $95^{\mathrm{a}}$ \\
\hline & S. secundatum & $6.7^{\mathrm{c}}$ & $7.3^{\mathrm{b}}$ & $6.6^{\mathrm{b}}$ & $7.1^{\mathrm{c}}$ & $75^{c}$ & $87^{c}$ \\
\hline & P. vaginatum & $6.7^{\mathrm{c}}$ & $7.3^{\mathrm{b}}$ & $6.6^{\mathrm{b}}$ & $7.4^{\mathrm{b}}$ & $75^{c}$ & $87^{c}$ \\
\hline & C. dactylon & $6.6^{\mathrm{c}}$ & $7.3^{\mathrm{b}}$ & $6.3^{\mathrm{c}}$ & $7.1^{\mathrm{c}}$ & $72^{\mathrm{d}}$ & $87^{c}$ \\
\hline & P. clandestinum & $6.6^{\mathrm{c}}$ & $7.0^{c}$ & $6.5^{\mathrm{b}}$ & $7.0^{c}$ & $72^{\mathrm{d}}$ & $84^{\mathrm{d}}$ \\
\hline
\end{tabular}

*From 1 (worst) to 9 (best); ${ }^{\circ}$ from 1 (completely brown) to 9 (bright green); ${ }^{\circ} \%$ of the plot covered by the green turf. In each column, means followed by different letters are significantly different (P<0.05; StudentNewman-Keuls's test).

these climatic conditions the species that showed the lowest value was P. clandestinum (4.8).

Similar results were observed for colour index and ground cover percentage. These parameters, for all species evaluated, were estimated $\geq 6.5$ and $\geq 80 \%$ applying the highest level of irrigation $\left(\mathrm{ET}_{0}=75 \%\right)$ during September, while they reached unsatisfactory values ( $\leq 5$ for colour index and $\leq 55 \%$ for ground cover percentage) when irrigated with the lower irrigation regimes during July-August. Within all species, P. clandestinum and $S$. secundatum gave the worst results.

The second year (2009), characterised by greater rainfall, let to observe a different trend. With exception for $P$. clandestinum and $S$. secundatum, the other species irrigated both with higher and lower irrigation regimes, gave for all months turf quality values greater than 6 . $P$. clandestinum and $S$. secundatum, irrigated in August with the lower irrigation regime, gave unsatisfactory values ranging around 5.7.

The highest values were recorded for $Z$. japonica (7.9), C. dactylon (7.7) and $P$. vaginatum (7.6). Colour index and ground cover percentage showed a similar trend with values higher than 6 and $60 \%$ for all species and irrigation treatments with exception for $S$. secundatum and $P$. clandestinum. The best values of colour index and ground cover percentage were collected in September for $Z$. japonica irrigated with higher $\mathrm{ET}_{0}$ restoration level and equals to 7.9 and $98 \%$ respectively. Once again, $S$. secundatum and $P$. clandestinum gave the worst results in August, with values below 5.5 and $55 \%$ with $\mathrm{ET}_{0} 50 \%$.

These results, confirm higher performances of $Z$. japonica and $P$. vaginatum when irrigated with adequate irrigation levels and with good climatic conditions (Gibeault et al., 1989; Miele et al., 2000; Cathey et al., 2011); P. clandestinum and S. secundatum proved the lowest degree of adaptability to hot and drought conditions when irrigated with inadequate water supply (Marais, 2001; Busey, 2003; Gross, 2003; Christians, 2007).

\section{Conclusions}

All the parameters estimated were highly affected by climate, in particular by rainfall.

Water regime restoring the $75 \%$ of the $\mathrm{ET}_{0}$ showed maximum effect on turf quality, colour index and ground cover only when rainfalls were scarce, although turfgrasses studied in our trial were not permanently damaged if irrigated with a lower volume $\left(50 \%\right.$ of $\left.\mathrm{ET}_{0}\right)$.

Under rainy conditions, also the restoration of the $50 \%$ of $\mathrm{ET}_{0}$ was able to give highly acceptable values.

Among the species studied in the trial, the best performance was recorded for $Z$. japonica, $C$. dactylon and $P$. vaginatum, whereas $P$. clandestinum and $S$. secundatum, showed lower adaptability to water stress.

Based on these results, we can conclude that higher irrigation volumes should be used on turfgrasses with functions that require great aesthetic value. Lower volumes can be applied in turfgrasses that can tolerate a temporary lowering of the quality parameters during period of higher water requirements. Such approach to irrigation management is useful in saving water resources and could make possible to grow turfgrasses also in dry environments.

\section{References}

Aronson LJ, Gold AJ, Hull RJ, Cisar JL, 1987. Cool-season turfgrass response to drought stress. Crop Sci. 27:1261-6.

Banuelos JB, Walworth JL, Brown PW, Kopec DM, 2011. Deficit irrigation of seashore paspalum and bermudagrass. Agron. J. 103:1567-77.

Bastug R, Buyuktas D, 2003. The effects of different irrigation levels applied in golf courses on some quality characteristics of turfgrass. Irrig. Sci. 22:87-93. 
Beard JB, 1985. An assessment of water use by turfgrass. In: V.A. Gibeault, S.T. Cockerman (Eds.), Turfgrass water conservation. Cooper. Ext. Publ.: 21405. University of California, Oakland, CA, USA, pp.45-61.

Biran I, Bravdo B, Bushkin-Harav I, Rawitz E, 1981. Water consumption and growth rate of 11 turfgrasses as affected by mowing height, irrigation frequency and soil moisture. Agron. J. 73:85-90.

Bowman DC, Macaulay L, 1991. Comparative evapotranspiration rates of tall fescue cultivars. Hort. Sci. 26:122-3.

Busey P, 2003. St. Augustinegrass, Stenotaphrum secundatum (Walt.) Kuntze. In: M.D. Casler, R.R. Duncan (Eds.), Turfgrass biology, genetics, and breeding. John Wiley \& Sons, Inc., Hoboken, NJ, USA, pp 309-30.

Carmo-Silva AE, Francisco A, Powers SJ, Keys AJ, Ascensao L, Parry MAJ, Arrabaca MC, 2009. Grasses of different $\mathrm{C}_{4}$ subtypes reveal leaf traits related to drought tolerance in their natural habitats: changes in structure, water potential, and amino acid content. Am. J. Bot. 96:1222-35.

Cathey SE, Kruse JK, 2011. Tolerance of three warm-season turfgrasses to increasing and prolonged soil water deficit. Hort. Sci. 46:1550-5.

Carrow RN, 1996. Drought avoidance characteristics of diverse tall fescue cultivars. Crop Sci. 36:371-7.

Cereti CF, Rossigni F, Nasetti F, 2004. Effect of water supply reduction on warm season grasses in Mediterranean environment. Acta Hort. 661:153-8.

Christians NE, 2007. Fundamentals of turfgrass management. $3^{\text {rd }}$ ed. John Wiley \& Sons, Hoboken, NJ, USA.

Feldhake CM, 1984. Turfgrass evapotranspiration. Response to deficit irrigation. Agron. J. 76:85-9.

Fu IJ, Huang B, 2004. Minimum water requirement of four turfgrasses in the transition zone. Hortic. Sci. 39:264-6.

Gibeault VA, Cocker-ham S, Henry JM, and Meyer J, 1989. California turfgrass: its use, water requirement and irrigation. Cal. Turf. Cul. 39:1-9.

Gomez KA, Gomez AA, 1984. Statistical procedures for agricultural research. John Wiley \& Sons, Hoboken, NJ, USA.

Gross PJ, 2003. Looking kindly at Kikuyugrass. USGA Green Section Record. 41:2-8.

Huang B, Duncan RR, Carrow RN, 1997a. Drought resistance mechanisms of seven warm-season turfgrasses under surface soil drying: I. Shoot response. Crop Sci. 37:1858-63.

Huang B, Duncan RR, Carrow RN, 1997b. Drought resistance mechanisms of seven warm-season turfgrasses under surface soil drying:
II. Root aspects. Crop Sci. 37:1863-9.

Kim KS, Beard JB, 1988. Comparative turfgrass evapotranspiration rates and associated plant morphological characteristics. Crop Sci. 28:328-31.

Kneebone WR, Kopec DM, Mancino CF, 1992. Water requirement and irrigation. In: D.V. Waddington, R.N. Carrow, R.C. Shearman (Eds.), Turfgrass; Monograph 32. ASA-CSSA-SSSA, Madison, WI, USA, pp 441-446.

Kopec DM, Shearman RC, Riordan TP, 1988. Evapotranspiration of tall fescue turf. Hort. Sci. 23:300-1.

Marais JP, 2001. Factors affecting the nutritive value of kikuyu grass (Pennisetum clandestinum) - a review. Trop. Grass. 35:65-84.

Marchione V, 2003. Influenza di due regimi irrigui, sull'accrescimento e su alcune caratteristiche estetiche di differenti graminacee micro e macroterme da tappeto erboso. Ital. Hort. 10:35-42.

Marchione V, 2012. Effect of different irrigation regimes on turf quality of warm-season species in Mediterranean climate. pp 48-50 in Proc. $3^{\text {rd }}$ Eur. Turfgrass Conf., June 24-26, Kristiansand, Norway.

Miele S, Volterrani M, Gaetani M, Grossi N, Pardini G, Chelini M, 1995. Modificazioni cromatiche di specie graminacee da tappeto erboso in conseguenza dello stress idrico. Riv. Agron. 29:152-9.

Miele S, Volterrani M, Grossi N, 2000. Warm season turfgrasses: results of a five-year study in Tuscany. Agric. Medit. 130:196-202.

Meyer JL, Gibeault VA, 1986. Turfgrass performance under reduced irrigation. Calif. Agric. 40:19-20.

Oula G, 2009. C4 photosynthesis and water stress. Ann. Botany 103:635-44.

Qian Y, Fry JD, 1997. Water relations and drought tolerance of four turfgrasses. J. Am. Soc. Hort. Sci. 122:129-33.

Qian Y, Engelke MC, 1999. Performance of five turfgrasses under linear gradient irrigation. Hort. Sci. 34:893-6.

Severmutlu S, Mutlu N, Gurbuz E, Gulsen 0, Hocagil M, Karaguzel 0, Heng-Moss T, Shearman RC, Gaussoin RR, 2011. Drought resistance of warm-season turfgrasses grown in Mediterranean region of turkey. Hort. Technol. 21:67-81.

Shearman RC, 1986. Kentucky bluegrass cultivar evaporation rates. Hort. Sci. 21:455-7.

Sifers SI, Beard JB, 1999. Drought resistance in warm-season grasses. Golf Course Mgt. 67:67-70.

William R, 1982. Consumption water use by sub-irrigated turfgrass under desert condition. Agron. J. 74:419-23.

Zhang X, Hu L, Bian X, Zhao B, Chai F, Sun X, 2007. The most economical irrigation amount and evapotranspiration of the turfgrasses in Beijing City, China. Agr. Water Manage. 89:98-104. 